\title{
Covid-19 Pandemic: Financial Impact and Intention to Stay in Current Business of Sabah Tamu Operators
}

\author{
Abdul Rahman Yaakob \\ Universiti Malaysia Sabah, Malaysia \\ Jaratin Lily \\ Universiti Malaysia Sabah, Malaysia \\ E-mail: jaratin@ums.edu.my \\ Sidah Idris \\ Universiti Malaysia Sabah, Malaysia \\ Zuraidah Jamrin \\ Universiti Malaysia Sabah, Malaysia
}

Received: November 10, 2021 Accepted: December 17, 2021 Published: December 24, 2021

doi:10.5296/ber.v11i4.19166 URL: https://doi.org/10.5296/ber.v11i4.19166

\begin{abstract}
In Sabah, Malaysia, a traditional market known as Tamu (means meeting) acts as a hub for local business activity, especially indigenous people. This paper presents an exploratory study whose goal is to investigate the Covid-19 pandemic financial impact and intention to stay in the current business of Tamu operators. Using purposive and snowballing sampling, survey data were collected from 125 Tamu business operators in Sabah. Among the respondents, 61.6 percent indicated Tamu business as their primary income and main entrepreneurial platform. The Covid-19 pandemic Movement Control Order (MCO) enforcement resulted in the Tamu entrepreneurs experiencing 34.2 percent decrease in weekly sales revenue and a 25.7 percent reduction in weekly gross profit. Furthermore, the overall mean score for the Tamu operators' intention to remain in the Tamu business is high at 4.37 based on 5-point likert scale. Thus, the Sabah Tamu operators are more likely to sustain their Tamu business despite the adverse financial impact of the Covid-19 MCO enforcement. This study outcome
\end{abstract}


may guide the relevant government agencies to mitigate the financial impact by formulating and implementing appropriate policies and support programs specifically targeted for the Tamu business operators, who are mostly informal entrepreneurs.

Keywords: Covid-19 pandemic, Movement Control Order, Financial impact, Intention to stay, Tamu business, Sabah

JEL Classification: L26, L81

\section{Introduction}

Like those of other countries, Malaysia's key aims are to increase employment opportunities and reduce poverty (Hatta \& Ali, 2013; Mulok et al., 2011; Siwar et al., 2016). In order to fulfil this strategy, Malaysian government has supported the development of entrepreneurship because by creating entrepreneurial ventures, they can contribute to job creation, economic development, poverty reduction, and other economic and social benefits (Hanafiah et al., 2016). Entrepreneurship is defined as the process of engaging in business objectives, achieving specific social or economic goals, and exploring new prospects using market-based approaches (Tur-Porcar et al., 2018).

Since the state's gaining independence, Sabah has undergone significant economic reforms. The consequences of these reforms have some indirect impacts on Sabah's entrepreneurial and business activity. Tamu, a native or traditional open-air market held in Sabah and Sarawak, is a communal area where local entrepreneurial and business activity occurs. Before supermarkets, hypermarkets, and commercial malls, Tamu became an important location for local farmers, fishermen, and hawkers to exchange goods items via barter trade or cash (Foo, 2018). Furthermore, Tamu serves as a social meeting place where villagers communicate with others, share important announcements and have exceptional celebration gatherings. Tamu is the most effective platform for disseminating news, particularly in remote areas, besides receiving reports from outpost areas.

Nowadays, Tamu markets are also located in major cities and towns throughout Sabah, including Kota Kinabalu and Doggongon in Penampang, one of the state's oldest Tamu. Moreover, one of the most significant ways tourists learn about Sabah local culture and lifestyle is to visit the Tamu markets. Indeed, Tamu has become one of Sabah's most popular tourist attractions, particularly those Tamu markets in Kota Belud, Donggongon, and Gaya Street of Kota Kinabalu. According to Sabah Tourism Board (2020), the best way to experience the melting port of Sabah is to visit the largest open-air market of the grand Tamu Besar held annually in Kota Belud. Besides the usual selling of products and everyday goods, the main highlights of the Kota Belud Tamu Besar include a colourful parade by the Bajau horsemen, the Ratu Serimpak Beauty pageant and the water-buffalo race. This annual Tamu Besar of Kota Belud was scheduled on 26 and 27 October 2020 but was cancelled because of the Covid-19 Movement Control Order.

However, the year 2020 was a challenging period for Malaysia, and most of the world due to the coronavirus infectious disease epidemic known as Covid-19. This infectious disease has had wide-ranging impact on various industries such as health, agriculture, tourism and travel, 
trade and retail, airlines transportation, and many more (Smith et al., 2019). In order to cope with the positive cases and casualties of the Covid-19 pandemic, many governments began imposing stringent measures through variety of limitations for safety precaution such as imposing state and country border control, social and physical people distancing, and requirement for individuals to wear a face mask (Shah et al., 2020; Zainudin et al., 2020).

With a relatively high number of positive Covid-19 cases, the Malaysian government has also adopted the Movement Control Order (MCO) to prevent Covid-19 transmission beginning from 18 March 2020 (Tang, 2020). During the MCO periods, most businesses except for selected essential services are ordered to temporarily halt operations until a set time within the respective MCO periods. At the same time, people are told to stay safe at home. Table 1 below reflects the various phases and dates of MCOs announced by the Malaysian Prime Minister and National Security Council in 2020 and the first quarter of 2021. Effective 11 January 2021, the MCO rulings also varied by state, depending on the Covid-19 situation in each state (Goh, 2021). Temporary openings of the Sabah Tamu markets were implemented with Covid-19 standard operating procedures during certain phases of Conditional Movement Control Order (CMCO) and Recovery Movement Control Order (RMCO).

Table 1. Movement Control Order by Phase in Malaysia

\begin{tabular}{|l|l|}
\hline Phase & Date \\
\hline \multicolumn{2}{|l|}{ Movement Control Order (MCO) } \\
\hline 1 & 18 March 2020 - 31 March 2020 \\
\hline 2 & 1 April 2020 - 14 April 2020 \\
\hline 3 & 15 April 2020 - 28 April 2020 \\
\hline 4 & 29 April 2020 - 3 May 2020 \\
\hline Conditional Movement Control Order (CMCO) \\
\hline 1 & 4 May 2020 - 12 May 2020 \\
\hline 2 & 13 May 2020 - 9 June 2020 \\
\hline Recovery Movement Control Order (RMCO) \\
\hline 1 & 10 June 2020 - 31 August 2020 \\
\hline 2 & 1 September 2020 - 31 December 2020 \\
\hline 3 & 1 January 2021 - 31 March 2021 \\
\hline
\end{tabular}

Source: Prime Minister's Office of Malaysia Official Website

A survey undertaken after the first nationwide MCO showed that nearly half of self-employed workers and a quarter of employers in Malaysia had gone through the MCO period without earning any income (Teoh, 2020). Furthermore, for those self-employed Malaysians who confirmed that they still had jobs, 94.8 percent suffered income losses, with more than a third of them experiencing salary cuts of over 90 percent (Department of Statistics Malaysia, 2020). Most respondents also highlighted that they were not financially prepared for further extension of the MCO periods.

These Covid-19 pandemic adverse situations have also significantly affected the Sabah Tamu business operators due to the required closure of their business platform of the Tamu markets. The negative effect had already been felt even before the first MCO period. This Tamu was 
significantly affected, especially from the end of 2019 and January 2020, due to the cancellation of international flights into Kota Kinabalu mainly because of initial Covid-19 cases in China, followed by positive cases in other parts of the world (Tang, 2020). Moreover, the MCO restriction on the Tamu markets had affected the Tamu entrepreneurs' weekly business operations. The extension of various MCO periods negatively affected their income, particularly those located in rural areas of Sabah.

Regarding business outcomes, most past studies have emphasized entrepreneurs' business performance (Souisa, 2018) and intention to become an entrepreneur (Koe et al., 2019; Samuel, 2013; Tsordia \& Papadimitriou, 2015). One of the recent studies examining entrepreneurs' intention is Hanafiah et al., (2016), but the study focused on the franchising industry. Additionally, many previous research mainly concentrated on small and medium-sized enterprises' (SMEs') entrepreneurial activities at the firm level instead of individual or sole proprietorship (Hanafiah et al., 2016; Koe et al., 2015; McCain, 2010). In this particular case, there is a lack of study about the intention of Tamu business operators to remain in their business despite facing challenges and restrictions. Therefore, the main objectives of this study are to investigate the financial impact of the Covid-19 pandemic on the local Tamu business operators and to examine their intention to stay in the Tamu business. Results of this study are expected to provide valuable insights regarding the Tamu business operators' characteristics that the relevant government agencies can use to lessen the financial impacts experienced by the Tamu entrepreneurs through appropriate policies and support programs.

\section{Methodology}

A structured questionnaire was constructed to collect primary data for the study using a cross-sectional methodology. Due to the limited and unstructured nature of the Tamu business operators' available data, this study used purposive and snowball sampling methods. The target population is the Tamu entrepreneurs running Tamu business activities in Sabah.

The survey questionnaire consists of three sections which are section A (Respondent's profile), section B (Financial impact), and section C (Intention to stay). For the intention to stay in the Tamu business, the respondents were asked to rate their degree of agreement or disagreement regarding their intention to remain in the Tamu business using a five-point Likert scale ranging from "1 strongly disagree" to "5 strongly agree". The questions on the intention to stay are adapted from Meyer's study (2018). Furthermore, this research collected data in two ways: through an on-site survey and online using Google forms. Between November 2020 and February 2021, questionnaires were sent to Tamu operators in several Tamu locations in Sabah. Snowball sampling was used in the area where the on-site Tamu markets were closed during the data collection period because of the MCO. There were 125 questionnaires successfully collected for data analysis from a total of 203 distributed to Tamu business owners, resulting in a 61.6 percent response rate.

\section{Results and Discussion}

This part presents the results and discussion of the respondents' profile, financial impact of 
the Covid-19 pandemic and intention to remain in Tamu business.

\subsection{Profile of Respondents}

Table 2. Profile of Respondents

\begin{tabular}{|c|c|c|}
\hline Category & Frequency & Percentage (\%) \\
\hline \multicolumn{3}{|c|}{ Tamu Business Location } \\
\hline West Coast & 28 & 22.4 \\
\hline Kudat & 31 & 24.8 \\
\hline Interior & 27 & 21.6 \\
\hline Tawau & 39 & 31.2 \\
\hline \multicolumn{3}{|l|}{ Gender } \\
\hline Male & 46 & 36.8 \\
\hline Female & 79 & 63.2 \\
\hline \multicolumn{3}{|l|}{ Marital Status } \\
\hline Single & 25 & 20.0 \\
\hline Married & 94 & 75.2 \\
\hline Divorce & 4 & 3.2 \\
\hline Widow & 2 & 1.6 \\
\hline \multicolumn{3}{|l|}{ Age } \\
\hline $18-24$ & 17 & 13.6 \\
\hline $25-34$ & 26 & 20.8 \\
\hline $35-44$ & 34 & 27.2 \\
\hline $45-54$ & 25 & 20.0 \\
\hline $55-64$ & 16 & 12.8 \\
\hline 65 and above & 7 & 5.6 \\
\hline \multicolumn{3}{|l|}{ Education } \\
\hline No Formal Education & 16 & 12.8 \\
\hline Primary & 23 & 18.4 \\
\hline Secondary & 67 & 53.6 \\
\hline Tertiary & 19 & 15.2 \\
\hline \multicolumn{3}{|l|}{ Type of Product } \\
\hline Agriculture & 44 & 35.2 \\
\hline Food and Beverage & 41 & 32.8 \\
\hline Clothing & 15 & 12.0 \\
\hline Household Item & 2 & 1.6 \\
\hline Fishery & 16 & 12.8 \\
\hline Poultry & 3 & 2.4 \\
\hline Others & 4 & 3.2 \\
\hline \multicolumn{3}{|l|}{ Year in Tamu Business } \\
\hline $0-5$ Years & 61 & 48.8 \\
\hline 6-10 Years & 42 & 33.6 \\
\hline 11-15 Years & 10 & 8.0 \\
\hline 16 years and above & 12 & 9.6 \\
\hline \multicolumn{3}{|c|}{ Purpose of Tamu Business } \\
\hline Primary Income & 77 & 61.6 \\
\hline Secondary Income & 44 & 35.2 \\
\hline Family Tradition & 4 & 3.2 \\
\hline
\end{tabular}

Analysis of the 125 data as illustrated in Table 2 above summarised that most of the respondents were female (63.2\%), married (75.2\%), aged 36-44 years (27.2\%), had 
secondary school education (53.6\%), involved in the Tamu business for five years and below $(48.8 \%)$ and undertaking business at the Tamu market as their primary source of income $(61.6 \%)$. Furthermore, the main types of products sold by the respondents were agriculture (35.2\%), and food and beverage (32.8\%). Other data analyses and discussions of the Tamu business operators' backgrounds are presented below.

\subsubsection{Business Location}

The data collected are also arranged according to four divisions in Sabah where the respondents are located, namely the West Coast, Kudat, Interior, and Tawau, especially for the subsequent data of Table 3 and 4. The West Coast division includes Tamu located in Kota Kinabalu, Penampang, Tuaran and Kota Belud. For Kudat area it comprises of Tamu in Kudat, Kota Marudu and Pitas. Meanwhile, Tamu markets in Keningau and Tambunan are part of the Interior region. Lastly, Tawau division includes those Tamu markets in Tawau, Semporna and Lahad Datu. The Tawau division recorded the highest number of Tamu respondents at 31.2 percent.

\subsubsection{Working Mode of Tamu Business Activity}

Majority 60 percent of the respondents undertaken Tamu business activity on full time mode whereas the balance 40 percent on part-time basis. These figures reflected that most of the respondents were focused entrepreneurs and spent considerable time on their Tamu business.

\subsubsection{Distance to Tamu Location}

As for distance to Tamu location, most 83.2 percent of the Tamu business operators do not travel more than 10 kilometres away from their residence. The furthest distance to Tamu location is $95 \mathrm{~km}$ by a respondent. Hence, there is a high tendency for the Tamu entrepreneurs to choose the Tamu location near their living areas, possibly for convenience and to reduce the cost of travel and transportation.

\subsubsection{Reason for Chosen Tamu Location}

Some 43.2 percent of the respondents specifically stated that their home residence is the main reason for Tamu's chosen location. Another 32.8 percent of respondents cited good customers response as the factor, while 13.6 percent were because of the day and time of the Tamu opening hours. Different Tamu operators have reasons for the Tamu locations that suit them best.

\subsubsection{Number of Tamu Workers}

The number of workers engaged by the Tamu business operators prior to the MCO mainly were not more than 2, whereby 31.2 percent of the respondents indicated having one employee, 27.2 percent with two workers, and 25.6 percent respondents were self Tamu entrepreneurs by not engaging any employee. Comparatively, most of the number of workers engaged by the Tamu business operators during the MCO periods were not more than two, whereby 40 percent of the respondents did not engage any employee, 32 percent indicated having one employee and 20 percent with two workers. 
Hence, fewer workers were employed for the Tamu business during the MCO period than before the restriction. Interestingly, many Tamu business operators did not utilize any workers during the MCO periods with 40 percent of the respondents compared to 25.6 percent prior to the MCO. This is due to nil or not much business activity because of the temporary Tamu markets closure.

\subsubsection{Number of Tamu Market Participated}

Regarding the number of Tamu market participated weekly prior to the MCO, some 32 percent of the respondents sold at 2 Tamu markets, while 23.2 percent at one Tamu every week. A few 6.4 percent of the Tamu operators did not participate in any Tamu. In comparison, 40.8 percent of the respondents did not join any Tamu during the MCO implementation, meaning a significant increase in non-participation in the Tamu markets. Those who continued selling during the MCO periods indicated one Tamu participation weekly for some 20.8 percent, two Tamu weekly for 8.8 percent, and seven Tamu weekly (average daily) for 10.4 percent of the respondents. Hence, some Sabah Tamu entrepreneurs managed to operate daily when the Tamu markets re-opened during certain phases of the MCO. This finding relates well to the objective of being in the Tamu business as primary source of income, as reflected in item 3.1.

\subsection{Financial Impact}

Table 3. Financial Impact by Area

\begin{tabular}{|l|l|l|l|l|l|l|l|l|}
\hline \multirow{2}{*}{ Area } & \multirow{2}{*}{ No. } & \multicolumn{3}{|l|}{ Prior MCO Period } & \multicolumn{2}{l|}{ From MCO period } & \begin{tabular}{l} 
Weekly \\
Percentage \\
\cline { 3 - 9 }
\end{tabular} \\
\cline { 3 - 9 } & $\begin{array}{l}\text { Weekly } \\
\text { Sales } \\
\text { Revenue } \\
(\mathrm{RM})\end{array}$ & $\begin{array}{l}\text { Weekly } \\
\text { Cost } \\
(\mathrm{RM})\end{array}$ & $\begin{array}{l}\text { Weekly } \\
\text { Gross } \\
\text { Profit } \\
(\mathrm{RM})\end{array}$ & $\begin{array}{l}\text { Weekly } \\
\text { Sales } \\
\text { Revenue } \\
(\mathrm{RM})\end{array}$ & $\begin{array}{l}\text { Weekly } \\
\text { Cost } \\
(\mathrm{RM})\end{array}$ & $\begin{array}{l}\text { Weekly } \\
\text { Gross Profit } \\
(\mathrm{RM})\end{array}$ & $\begin{array}{l}\text { Gross } \\
\text { Profit }(\%)\end{array}$ \\
\hline Tawau & 39 & 772.40 & 344.70 & 427.80 & 563.30 & 259.50 & 303.90 & -29.0 \\
\hline West Coast & 28 & 679.60 & 445.00 & 234.60 & 349.50 & 204.50 & 145.00 & -38.1 \\
\hline Kudat & 31 & 860.50 & 460.10 & 400.40 & 579.30 & 213.30 & 366.10 & -8.5 \\
\hline Interior & 27 & 634.30 & 615.30 & 19.00 & 425.40 & 439.90 & -14.60 & -176.8 \\
\hline Total & 125 & 743.60 & 454.20 & 289.40 & 489.60 & 274.70 & 214.90 & -25.7 \\
\hline
\end{tabular}

Note: $\mathrm{RM}=$ Ringgit Malaysia

Table 3 above shows the financial impact to the Tamu business operators by area in Sabah prior to and from the MCO period of 18 March 2020. The figures are reflected in average weekly sales revenue, average weekly cost incurred, and average weekly gross profit for each area, together with the consequential average weekly total of these financial components.

Before the MCO period, Tawau, the West Coast, Kudat and Interior regions recorded average weekly gross profit amounts of RM427.80, RM234.60, RM400.40 and RM19.0, respectively resultant average weekly total gross profit of RM289.40 for the 125 Tamu business operators. Tawau and Kudat regions had higher average weekly gross profit because the average cost in Tawau was the lowest at RM344.70. In contrast, the average sales revenue in Kudat was the highest at RM860.50. The Interior division had very little average weekly gross profit due to 
its highest average cost of RM615.30. The relatively remote location of Tamu markets in the Sabah Interior region may contribute to such a high cost incurred.

On the contrary, beginning from the MCO period of 18 March 2020 with certain temporary closure periods of the Tamu markets, every area in this study generated lesser average weekly sales revenue and correspondingly lower average weekly cost, which resulted in lower average weekly gross profit earned as compared to prior the MCO period. From implementing the MCO phases, Tawau accumulated an average weekly gross profit of RM303.90, the West Coast of RM145.00, and Kudat with an average weekly gross profit of RM366.10. Meanwhile, the Interior region recorded a negative average weekly gross profit of - RM14.60 because its average cost was the highest at RM439.90 despite earning an average weekly sales revenue of RM425.40, the lowest average revenue generated among the four areas. Although negative average weekly gross profit was generated for the Interior region, the overall average gross profit for the four areas effective the MCO periods was RM214.90.

In summary, the Interior division had the worst financial impact with -176 percent average weekly gross profit between the two periods before and after the MCO implementation. The other three areas also recorded average weekly gross profit differential between the periods but with a lesser percentage of -8.5 percent for Kudat, -29.0 percent for Tawau, and -38.1 percent for the West Coast, henceforth resulting in -25.7 percent for overall average weekly gross profit for all four regions. None of the areas as capable of sustaining its profitability from the Tamu business when the MCO periods were in effect, mostly arising from the inability to conduct business because of the Tamu markets closure order by the National Security Council and the Sabah state government. When the Tamu markets had temporary re-opening, the average weekly sales revenue generated and average weekly cost incurred were shown in Table 3 above, resulting lower amounts obtained than before the MCO period.

The above finding of negative financial impact to the Tamu business operators, particularly when the MCO took effect, is somewhat consistent with the statement made by Malaysian Domestic Trade and Consumer Affairs (MDTCA) Minister Datuk Seri Alexander Nanta Linggi. They pointed out that micro and informal enterprises were severely affected by the Covid-19 induced MCO because their products and services are in the non-essential sector. They tend to have lack savings and strong cash flow (Bernama, 2021). According to the Bernama report, the Minister's statement was based on the findings of an online survey by SME Corporation Malaysia (SME Corp) conducted by the Entrepreneur Development and Cooperatives Ministry (MEDAC) from 15 February until 5 March 2021 involving 3,855 entrepreneurs throughout Malaysia regarding the impact of $\mathrm{MCO}$ on the industry. Furthermore, the SME Corp's and MEDAC's study findings were considered alarming by the MDTCA Minister because micro and informal entrepreneurs are the most common type of businesses in Malaysia, and consequently it is almost unimaginable to him and the government agencies on how much the business owners have had to endure during difficult times of MCO of the Covid-19 pandemic.

Many Tamu business operators in Sabah are informal entrepreneurs because they do not formally register their business as an enterprise or company. Hence, regretfully most of these 


\section{$\Lambda$ Macrothink}

Business and Economic Research ISSN 2162-4860 2021, Vol. 11, No. 4

Tamu entrepreneurs also had experienced the same difficult financial situation as those of the micro and informal entrepreneurs located in other parts of Malaysia during the Covid-19 MCO enforcement. Moreover, as reflected in Table 3, the Sabah Tamu business operators suffered 25.7 percent average weekly profit reduction during the implementation of the MCO periods.

\subsection{Intention to Stay in the Tamu Business}

This part presents the results and discussion of the intention to stay in Tamu business as reflected in Table 4 below according to the survey questions adapted from Meyer (2018), who studied South African female entrepreneurs' intention to remain in business. According to Meyer (Meyer, 2018), some factors may be related to the intention to remain in or grow the business. Exogenous factors such as demographics, traits and situations, for example, government support and policy, may influence the intention and attitude of an individual. Moreover, intention and attitude are also contributed by the individual's characteristics and motivation. Entrepreneurs have jobs and tasks when they start and manage a business despite not having jobs in the traditional sense (Hanafiah et al., 2016). This also relates to the Tamu business operators, who are mostly informal entrepreneurs. Henceforth, the questionnaire by Meyer (2018) is adapted to suit the context of this study, which focused on Sabah Tamu business operators' intention to stay in the Tamu business.

Table 4. Intention to Stay in the Tamu Business

\begin{tabular}{|l|l|l|l|}
\hline Description & No. & Mean \\
\hline I like having a work life balance & Tawau & 39 & 4.26 \\
\cline { 2 - 4 } & West Coast & 28 & 4.82 \\
\cline { 2 - 4 } & Kudat & 31 & 4.65 \\
\cline { 2 - 4 } & Interior & 27 & 4.30 \\
\cline { 2 - 4 } & Total & 125 & 4.49 \\
\hline I prefer being my own boss & Tawau & 39 & 4.28 \\
\cline { 2 - 4 } & West Coast & 28 & 4.46 \\
\cline { 2 - 4 } & Kudat & 31 & 4.39 \\
\cline { 2 - 4 } & Interior & 27 & 3.96 \\
\cline { 2 - 4 } & Total & 125 & 4.28 \\
\hline I desire more wealth and economic stability & Tawau & 39 & 3.97 \\
\cline { 2 - 4 } & West Coast & 28 & 4.39 \\
\cline { 2 - 4 } & Kudat & 31 & 4.42 \\
\cline { 2 - 4 } & Interior & 27 & 4.48 \\
\cline { 2 - 4 } & Total & 125 & 4.29 \\
\hline I like being creative and using my talents & Tawau & 39 & 4.36 \\
\cline { 2 - 4 } & West Coast & 28 & 4.79 \\
\cline { 2 - 4 } & Kudat & 31 & 3.61 \\
\cline { 2 - 4 } & Interior & 27 & 4.30 \\
\cline { 2 - 4 } & Total & 125 & 4.26 \\
\hline I like to grab new opportunity(ies) in the market & Tawau & 39 & 4.36 \\
\cline { 2 - 4 } & Test Coast & 28 & 4.50 \\
\cline { 2 - 4 } & Kudat & 31 & 3.97 \\
\cline { 2 - 4 } & Interior & 27 & 4.15 \\
\cline { 2 - 4 } & Total & 125 & 4.25 \\
\hline I like pursuing challenge(s) & & 39 & 4.33 \\
\hline
\end{tabular}




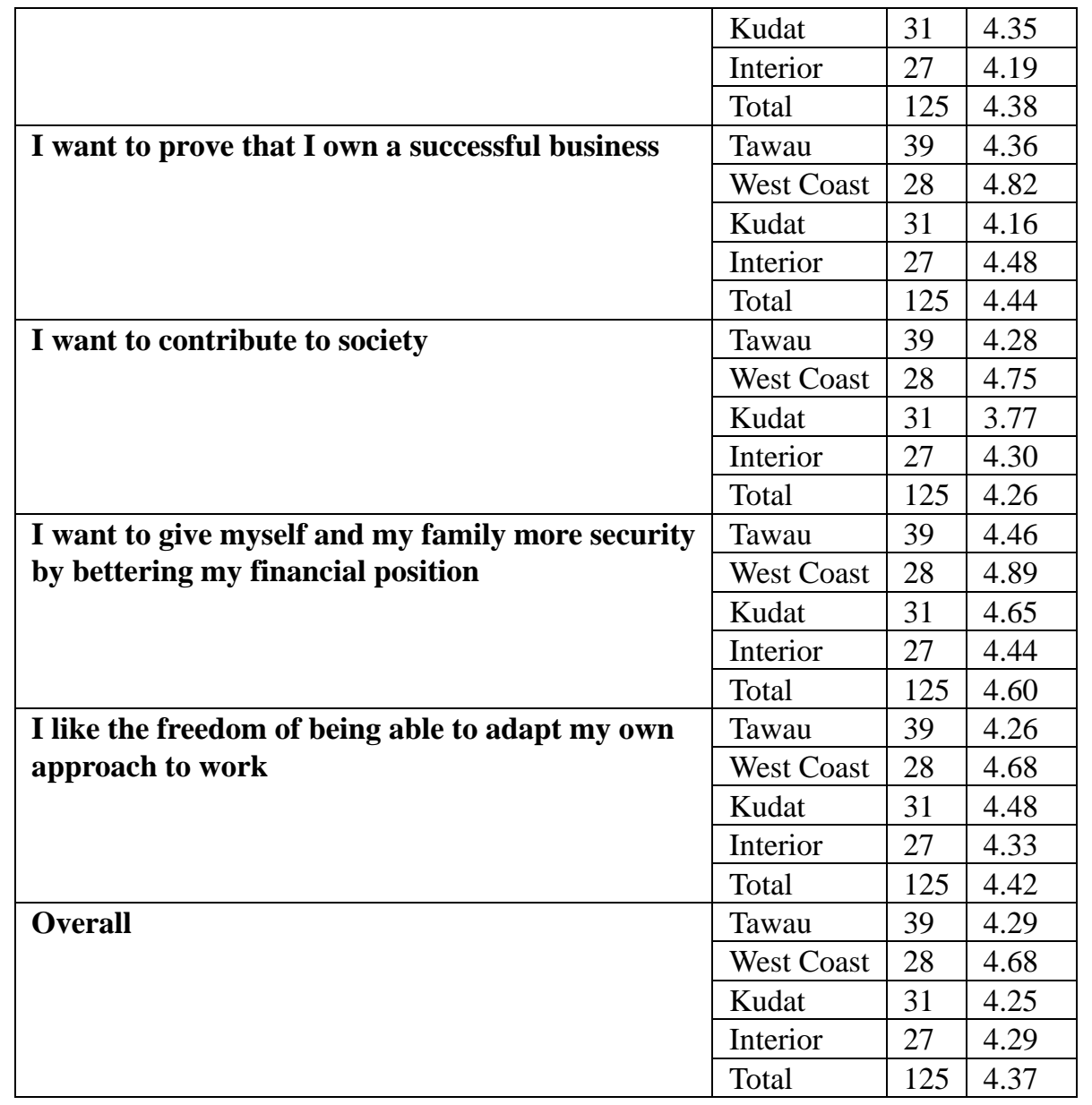

Note: 1 = Strongly Disagree, 5 Strongly Agree

The results are presented under various sub-headings for clarity and understanding. Only mean scores of the five Likert-scale are used and stated because the analysis is mainly descriptive.

\subsubsection{Like Having a Work Life Balance}

The results illustrated that the mean scores for the Tamu business respondents who like to have a work-life balance are all high because of above 4.00. The West Coast Sabah region recorded the highest mean at 4.82 , while the overall mean for this item is 4.49 . Hence, most Tamu business operators prefer to have work-life balance rather than fully concentrating on their work. Balancing life with spending quality individual's time with family and friends is equally essential in selling their products at Tamu markets. This work-life balance preference may also relate to the composition of the respondents whereby the majority, 65.6 percent with the age of 35 and above, and 75.2 percent of the Tamu operators are married who may value family commitment as equally crucial to working or being an entrepreneur.

\subsubsection{Prefer Being My Own Boss}

Tawau, the West Coast and Kudat regions achieved high mean scores for preference of being 
own boss or superior with scores of $4.28,4.46$ and 4.39 respectively. However, the Interior division's mean score is in the upper average category. Thus, instead of being own supervisor, the Tamu business operators in the Interior region tend to opt for working or selling for someone else compared to those in the three regions which appear to strive for being self-entrepreneur and own superior. Many Tamu business owners are informal entrepreneurs who mainly sell at relatively small-scale volumes of the products, thus their desire to be own boss for their own satisfaction instead of serving others in the Tamu business. Nevertheless, the respondents in the Interior division may have minimal financial means or selling resources, resulting in some of them preferring to work for other people.

\subsubsection{Desire More Wealth and Economic Stability}

Regarding desire for more wealth and economic stability, the Tamu entrepreneurs in the West Coast, Kudat and Interior areas recorded high mean scores of 4.39, 4.42 and 4.48, respectively. In contrast, Tawau reflected an average mean result of 3.97. Hence, most of the respondents desire more wealth and economic stability, which may influence them to participate in the Tamu business as the primary source of income. Incomes derived from the Tamu business can provide economic stability, especially to the own self and family of the Tamu operators. Those in rural areas of Sabah, such as in the remote villages and the Interior division may depend much on the Tamu business income for daily living expenses or for other self-related and family purposes. Furthermore, if the Tamu business can generate much sales revenues and profits, it correspondingly contributes to the wealth status of the Tamu entrepreneurs.

\subsubsection{Like Being Creative and Using My Talents}

Most Tamu business operators in the West Coast of Sabah like being creative and using their talents as reflected in very high mean score of 4.79. The West Coast includes Tamu in some urban areas of Kota Kinabalu, Penampang and Tuaran which has more opportunities for creative exposure and displaying of individual talents. Moreover, preference for own creativity and talent is also high in Tawau and the Interior region with mean scores of 4.36 and 4.30, respectively. Notwithstanding, Tamu business operators in the Kudat division have a relatively average preference for being creative and using their own talents. Many of the Kudat respondents are more likely to be followers by adopting past practices rather than using their own talent and capabilities in undertaking a particular business or activity. Additionally, during the Tamu closures because of Covid-19 MCO, some Tamu entrepreneurs may become creative by utilizing alternative mode of distribution and selling, for instance through joint pooling of their products with other sellers by using the same logistics delivery service or provision of own transportation to market the products to the customers.

\subsubsection{Like Pursuing Challenge(s)}

For pursuing challenges, the outcomes are almost similar with item 3.3.4 of being creative and using own talents, whereby the West Coast, Tawau and Interior areas recorded high mean scores of 4.50, 4.36 and 4.15, respectively, compared to Kudat's upper average score of 3.97. These results indicate that the Kudat respondents tend to be less risk-takers in pursuing life 
challenges and possibly business activities. Those in the West Coast, Tawau and Interior are more willing to pursue challenges that they encounter. Having strong determination and self-resilience is important, especially during the Covid-19 MCO periods in which Tamu markets are temporarily closed, affecting the income of the Tamu entrepreneurs. After all, taking risks such as pursuing challenges is an essential element of the traditional definition of an entrepreneur (Meyer, 2018; Wei et al., 2019).

\subsubsection{Like to Grab New Opportunity(ies) in the Market}

All four divisions obtained high mean scores concerning the Tamu business operators' likeness of taking new market opportunities. The West Coast region achieved the highest mean result of 4.64, followed by Kudat, Tawau and Interior areas with the mean point of 4.35, 4.33 and 4.19, respectively. Respondents in the West Coast region are more likely than the others to grab new opportunities due to many urban Tamu in the area with the vast latest market opportunities. In contrast, the Interior division's lack of new opportunities in the Tamu business resulted in slightly less liking to grab new opportunities in the markets.

\subsubsection{Want to Prove That I Own a Successful Business}

Most Tamu business operators in the West Coast want to prove that they own a successful business, as reflected in the very high mean score of 4.82. The other three areas of Interior, Tawau and Kudat, achieved a high mean score of 4.48, 4.36 and 4.16, respectively. Meyer (2018) found that job satisfaction affects the decision to remain in business based on a study on franchisee owners. Hence, past job satisfaction in running the Tamu business to a certain extent influence the Tamu entrepreneurs to remain in the business because they are generally optimistic, aiming for business success despite facing problems and challenges. This relates well to the situation of the Covid-19 MCO whereby although experiencing negative financial impact because of the Tamu market closures, there is a significant number of the Tamu business operators who still have the strong drive and determination to own successful business. They may view the adverse effects as temporary, thus they decide to keep sustaining the Tamu business when the markets re-open.

\subsubsection{Want to Contribute to Society}

Respondents in the West Coast have high regard for contributing to society, as reflected in a high mean score of 4.75. Those in the Interior and Tawau divisions also highly want to contribute to society. Each scored mean of 4.30 and 4.28 respectively. However, Tamu business operators in the Kudat area have average mean of 3.77, reflecting their lesser desire to contribute to the society compared to the other three regions. It can be concluded that many Tamu entrepreneurs are not serving for their self-interest and family wealth only, but instead also taking strong consideration of social responsibility to society and their community. Moreover, this finding corresponds very well to item 3.3.1 of preference for work-life balance because the Tamu entrepreneurs can achieve the quality of life through contribution to society. 
3.3.9 I Want to Give Myself and My Family More Security by Bettering My Financial Position

All four regions achieved high mean scores for the Tamu business operators to give themselves and their families more security by bettering their financial positions. The West Coast area scored the highest mean at 4.89, followed by Kudat (4.65), Tawau 4.46, and the Interior division 4.44. In addition, the overall mean for this item is the highest at 4.60 among all ten questionnaire items in this section, which largely reflects the importance of improving self financial position for the security well-being of the Tamu entrepreneurs and their families. These results are quite related to item 3.3.3 for the desire for more wealth and economic stability except that the description of this item 3.3.9 is more specific, focusing on bettering financial position for the security of oneself and family, thus noting higher mean scores than for item 3.3.3. Furthermore, the importance of family security is also emphasized and asked in this item 3.3.9, which results somewhat revealed the family orientated culture of the Sabah Tamu entrepreneurs.

\subsubsection{Like The Freedom of Being Able to Adapt My Own Approach to Work}

Most of the respondents like the freedom to adapt their own approach to work as shown by the high mean score results for all four divisions of the West Coast at 4.68, Kudat 4.48, Interior 4.33, and Tawau of 4.26. Instead of merely following others' way and method of work, the Tamu business operators in this study mainly value their self freedom in undertaking their approach to work tasks performed. To a certain extent, the informal business practices in the Tamu markets may influence the likeness of the Tamu entrepreneurs for freedom of being flexible using their own way of conducting their business.

In summary, the Sabah Tamu entrepreneurs intend to remain in their Tamu business despite the financial implication and other challenges they faced because of the Covid-19 MCO. This is reflected from the overall high mean score of 4.37 for all ten items used to measure the Tamu operators' level of intention to sustain their respective Tamu businesses. Moreover, from Tamu specific location's perspective, all four divisions achieved high mean points for the intention to continue maintaining the Tamu business with the West Coast, Interior, Tawau, and Kudat regions scored 4.68, 4.29, 4.29, and 4.25, respectively. Hence, it is expected that most of these Tamu operators will resume and sustain their business when the MCO enforcement is uplifted by the government and the Tamu markets re-open.

\section{Conclusion and Recommendation}

In conclusion, many Tamu business operators in Sabah have a strong desire to sustain their current business because Tamu is their primary business platform and source of income. Any additional MCO enforcement period with a directive for Tamu market closure is forecasted to have a significant negative financial impact on the Tamu businesses. Henceforth, the study results can provide insights into the Tamu operators' intention to stay in business despite the financial difficulty encountered arising from the Covid-19 MCO restriction. The findings may guide the relevant government ministries and agencies such as MDTCA, MEDAC and the state government to mitigate the financial impact by formulating and implementing 
appropriate policies and support programs specifically targeted for the Tamu business operators, who are mostly informal entrepreneurs.

The Covid-19 MCO imposed by the Malaysian and Sabah state government had caused limited access to gain more respondents for this study because the number of operators at Tamu markets per day had been drastically reduced with the temporary closures. This is also partly due to the weekly rotation system adopted by the local Sabah authorities such as in the Sandakan area for the Tamu business operators when the markets were allowed to open for certain phases of the MCO. Furthermore, due to the Covid-19 cases, some Tamu entrepreneurs were reluctant to answer the questionnaires distributed manually. Thus, for future research, it is recommended that local Tamu business operators associations to be involved as well to secure more respondents to participate without having an on-site survey at the Tamu markets, particularly if the MCO enforcement is in effect.

\section{Acknowledgments}

This research was financed by the Universiti Malaysia Sabah under the Special Grant Scheme (SDK0218-2020). The authors gratefully acknowledge the inputs and valuable assistance by the research enumerators especially in terms of access to the Tamu business operators including during the Covid-19 MCO periods. The authors also thank all key informants and related organizations that provided valuable time and knowledge.

\section{References}

Bernama. (2021, September 16). Micro and informal enterprises badly hit by MCO for not having enough savings - Nanta. [Online] Available:

https://www.bernama.com/en/news.php?id=2003854

Department of Statistics Malaysia. (2020). Report of Special Survey on Effects of COVID-19 on Economy and Individual - Round 1. [Online] Available:

https://www.dosm.gov.my/v1/index.php?r=column/cone\&menu_id=d3pnMXZ4ZHJjUnpnYj NyUnJhek83dz09

Foo, J. (2018). Penglibatan Komuniti Tempatan dalam Pasaran Tumbuhan Ubatan di Tamu Pantai Barat Sabah. Akademika, 88(April), 35-47.

https://doi.org/10.17576/akad-2018-8801-03

Goh, H. C. (2021). Strategies for post-Covid-19 prospects of Sabah's tourist market Reactions to shocks caused by pandemic or reflection for sustainable tourism? Research in Globalization, 3, 100056. https://doi.org/10.1016/j.resglo.2021.100056

Hanafiah, M. H., Yousaf, S. U., \& Hashim, N. A. (2016). Entrepreneurs' intention to invest in current business: An empirical study of Malaysian SME entrepreneurs. Geografia Malaysian Journal of Society and Space, 12(2), 119-131.

Hatta, Z. A., \& Ali, I. (2013). Poverty Reduction Policies in Malaysia: Trends, Strategies and Challenges. Asian Culture and History. https://doi.org/10.5539/ach.v5n2p48

Koe, W.-L., Alias, N. E., \& Othman, R. (2019). Factors Influencing the Intention towards 
Sustainable Entrepreneurship among University Students. International Journal of Academic Research in Business and Social Sciences, 9(9), 182-191.

https://doi.org/10.6007/IJARBSS/v9-i9/6283

Koe, W.-L., Omar, R., \& Sa'ari, J. R. (2015). Factors Influencing Propensity to Sustainable Entrepreneurship of SMEs in Malaysia. Procedia - Social and Behavioral Sciences, 172, 570-577. https://doi.org/10.1016/j.sbspro.2015.01.404

McCain, R. A. (2010). Entrepreneurship and Small Business. Southren African Business Review, 14(3), 131-153. https://doi.org/10.1142/9789813231252_0004

Meyer, N. (2018). South African Female Entrepreneurs' Intention to Remain in Business (Issue May) [North-West University]. [Online] Available:

https://repository.nwu.ac.za/handle/10394/31976

Mulok, D., Asid, R., Kogid, M., \& Lily, J. (2011). Economic Growth and Population Growth : Empirical Testing Using Malaysian Data. Interdisciplinary Journal of Research in Business, $1(5), 17-24$.

Sabah Tourism Board. (2020). Tamu Besar Kota Belud. [Online] Available:

https://www.sabahtourism.com/premier-events/tamu-besar-kota-belud/

Samuel, Y. A. (2013). An Assessment of Entrepreneurship Intention Among Sunyani Polytechnic Marketing Students. International Review of Management and Marketing, 3(1), $37-49$.

Shah, A. U. M., Safri, S. N. A., Thevadas, R., Noordin, N. K., Rahman, A. A., Sekawi, Z., Ideris, A., \& Sultan, M. T. H. (2020). COVID-19 outbreak in Malaysia: Actions taken by the Malaysian government. International Journal of Infectious Diseases, 97, 108-116.

https://doi.org/10.1016/j.ijid.2020.05.093

Siwar, C., Ahmed, F., Bashawir, A., \& Mia, M. S. (2016). Urbanization and Urban Poverty in Malaysia: Consequences and Vulnerability. Journal of Applied Sciences.

https://doi.org/10.3923/jas.2016.154.160

Smith, K. M., Machalaba, C. C., Seifman, R., Feferholtz, Y., \& Karesh, W. B. (2019). Infectious disease and economics: The case for considering multi-sectoral impacts. One Health, 7(January), 100080. https://doi.org/10.1016/j.onehlt.2018.100080

Souisa, W. (2018). The effects of entrepreneurial orientation and market orientation on business performance. Journal of Entrepreneurship Education, 21(4), 210-222.

Tang, K. H. D. (2020). Movement control as an effective measure against Covid-19 spread in Malaysia: an overview. Journal of Public Health (Germany), 17-20.

https://doi.org/10.1007/s10389-020-01316-w

Teoh, S. (2020). Coronavirus: Malaysian survey shows half of self-employed, quarter of employers without income due to outbreak. The Straitstimes.Com. [Online] Available: https://www.straitstimes.com/asia/se-asia/coronavirus-malaysian-survey-shows-half-of-self-e 
mployed-quarter-of-employers-without

Tsordia, C., \& Papadimitriou, D. (2015). The Role of Theory of Planned Behavior on Entrepreneurial Intention of Greek Business Students. International Journal of Synergy and Research, 4(1), 23. https://doi.org/10.17951/ijsr.2015.4.1.23

Tur-Porcar, A., Roig-Tierno, N., \& Llorca Mestre, A. (2018). Factors Affecting Entrepreneurship and Business Sustainability. Sustainability, 10(2), 452.

https://doi.org/10.3390/su10020452

Wei, J., Chen, Y., Zhang, J., \& Gong, Y. (2019). Research on factors affecting the entrepreneurial learning from failure: An interpretive structure model. Frontiers in Psychology, 10(JUN), 1-10. https://doi.org/10.3389/fpsyg.2019.01304

Zainudin, S. P., Mohd Kassim, M. A., \& Mohamad Ridza, N. N. (2020). Mitigation Measures during Elections and It's Impacts on COVID-19 Pandemic: Sabah State (Malaysia), New Zealand and the United States. Borneo Epidemiology Journal, 1(2), 145-156. [Online] Available: https://jurcon.ums.edu.my/ojums/index.php/bej/article/view/2748/1800

\section{Copyright Disclaimer}

Copyright for this article is retained by the author(s), with first publication rights granted to the journal.

This is an open-access article distributed under the terms and conditions of the Creative Commons Attribution license (http://creativecommons.org/licenses/by/4.0/). 